\title{
$\underline{\text { In Memory of Evgenii Alekseevich Kostiukhin }}$
}

Evgenii Kostiukhin passed away on January $4^{\text {th }}, 2006$ in St. Petersburg. Every Russian folklorist knew and admired his many publications, reports at conferences, and especially his conversations between sessions. He was born February 23, 1938 in the city of Verkhniaia Salda in Sverdlov oblast'. In 1955 he entered Moscow University to study in the Philological Faculty. His time at the university (1955-1960) coincided with the "Khrushchev Thaw," when the study of Russian folklore slowly began to return to methodological pluralism, thereby allowing the investigation of folk culture from as variety of standpoints. Kostiukhin belonged to the new generation of folklorists emerging at this time, who revived and broadened the study of folklore in Russia.

Like many of his colleagues, Kostiukhin took part in field expeditions. In the years 1956-1957 the Folklore Department at Moscow University organized field trips to selected areas in the Russian North "in the steps of the Sokolov brothers." A number of students who participated in these field trips subsequently became outstanding folklorists. 1958 witnessed Kostiukhin's first appearance in print in the form of a report on an expedition, which was published in the Vestnik of Moscow University. The most important teacher of this generation of Moscow folklorists was E. V. Pomerantseva, a remarkable connoisseur of the Russian folk tale. It is from her that Kostiukhin acquired his interest in the genre. In 1959, while still a student, he published an article in the journal Russkii fol'klor about recording tales during his expeditions to Karelia.

After graduating from Moscow University, Kostiukhin became a graduate student at the Kazakh Pedagogical Institute (1960-1963). When he finished his graduate work there, he taught in various pedagogical institutes in Kazakhstan and then spent 1977-1980 teaching in the Polish city of Bydgoszcz. Kostiukhin's dissertation, which he defended in 1969, was devoted to works about Alexander the Great in folklore and literature. He brought out his first book, Aleksandr Makedonskii v literaturnoi $\mathrm{i}$ fol'klornoi traditsii (Alexander the Great in literary and folklore tradition) in 1972. His work provided a many-sided and insightful reading of a popular subject about the life and deeds of this military leader as they appear in the literature of various peoples in the East and West. 
The twenty-two years Kostiukhin spent in Central Asia are reflected in his scholarship. In 1979 he participated in publication of a collection entitled Kazakhskie skazki o zhivotnykh (Kazakh animal tales). Later he prepared the commentary for collections of Kurdish and Tajik tales, legends, and traditions, and offered a historical-topological analysis of the plots. He analyzed the interaction of Russian and Kazakh tales in several articles. His prime interest lay in the typology of folklore contacts in prose tales.

In 1983 Kostiukhin moved to Leningrad and began teaching in the Herzen Institute, first as a docent and then as a professor. He gave courses not only on folklore, but also on eighteenth-century Russian literature and literary theory. These interests were reflected in the anthology entitled Prikliucheniia slavianskikh vitiazei: Iz russkoi belletristiki XVIII veka (The adventures of Slavic knights: An aspect of eighteenth-century Russian belles-lettres) (Moscow, 1988).

In 1988 Kostiukhin defended his doctoral dissertation Tipy i formy zhivotnogo eposa (The types and forms of the animal tale), which had been published the year before. This book is an outstanding example of the application of the historical-typological method to research in folklore. Animal tales of all types and from various peoples are examined in the spirit of the Russian comparativist A. N. Veselovskii. Kostiukhin has also devoted a number of articles to the heritage of this exceptional scholar, who was often officially reviled in the Soviet period.

In June 1989 Kostiukhin became a member of the Institute of Russian Literature (Pushkin House), Russian Academy of Sciences. "Perestroika" and the ensuing post-Soviet period opened the study of Russian folklore to new topics previously forbidden to scholars. In 1997, together with colleagues in Pushkin House, Kostiukhin published Narodnye russkie skazki ne dlia pechati, zavetnye poslovitsy $\mathrm{i}$ pogovorki, sobrannye i obrabotannye A. F. Afanas'evym (Russian folk tales not for publication, secret proverbs and sayings, collected and edited by A.N.Afanas'ev) (1857-1862). Here Kostiukhin contributed the introduction and a commentary, each concise and lucid. The "cruel romance," which folklorists had despised, also formed the subject of an article published in the journal Russkaia literatura, as well as in the volume of collected papers, Sovremennyi gorodskoi fol'klor (Contemporary urban folklore) (Moscow, 2003). The article "Khristianskie motivy v vostochnoslavianskom detskom fol'klore" (Christian motifs in East-Slavic children's folklore), which came out in the almanac Kanun in 1998, was influenced by the contemporary study 
of folklore in popular Orthodoxy. Several other works are devoted to children's folklore, a subject which for many decades had escaped the attention of scholars.

In the last few years of his life Kostiukhin edited and republished several classics of Russian folklore. Among them are I. M. Snegirev's Russkie narodnye poslovitsy i pritchi (Russian folk proverbs and parables) (Moscow, 1999), I. A. Khudiakov's two collections, Velikorusskie skazki (Great Russian tales) and Velikorusskie zagadki (Great Russian riddles) (St Petersburg, 2001), and D. N. Sadovnikov's Skazki i predaniia Samarskogo kraia (Tales and legends of the Samara region) (St Petersburg, 2003). In 2004 he came out with yet another book, Kodga zveri govorili: trista sem'desiat piat' mifov, skazok, basen, anekdotov, legend i predanii o zhivotnykh (When animals used to speak: Three hundred and seventy five myths, tales, fables, anecdotes, legends, and traditions about animals).

Kostiukhin was well-known abroad through his participation in international conferences, membership of editorial boards (Enzyklopädie des Märchens), and his publications. For his book, Lektsii po russkomu fol'kloru (Lectures on Russian folklore) (Moscow, 2004) he was awarded the Pitere-Solomone Marino international prize (Palermo). Evgenii Kostiukhin's death came as a shock to those who were close to him even though they knew the medical prognosis. Our memory of him will endure and his scholarly works will surely be a resource for succeeding generations of folklorists.

Tatyana Ivanova.

Institute of Russian Literature, RAN.

Translated by James Bailey and Faith Wigzell. 